\title{
IMPACT OF COVID-19 ON EVENT INDUSTRY: EVENT AUDIENCE READINESS TOWARDS EVENT DIGITIZATION
}

\author{
Marry Tracy Pawan ${ }^{1} \&$ Juliana Langgat ${ }^{2}$ \\ ${ }^{1,2}$ Faculty of Business, Economics and Accountancy, Universiti Malaysia Sabah \\ (marrypawan@ums.edu.my, juelanggat@ums.edu)
}

\begin{abstract}
For the event organiser, Sabah is one of the states that becomes a focal point. As Sabah is one of the most popular tourist destinations, several large events such as the Sabah Jazz Festival, Pesta Lepa-lepa, Pesta Kaamatan, Pesta Kalimaran, and other festivals have been held. However, COVID 19's disruptive impacts have had such a significant impact on the event sector. Most of the events are getting cancelled or postponed all over the world. Over the past several months, a significant number of meetings and conferences have been redesigned as virtual events. However, the event industry needs to know the readiness of the public towards the shifting from the physical to the digital. Therefore, the objective of this research is to determine the event audience readiness for digital events. It is important for the event industry to know the readiness and a good online platform in providing a good service to their audience. A quantitative method was used to conduct this study. The main finding will see how far our communities is ready to adapt the new norm. Based on the finding it shows that event audience are willing to adopt the event digitisation, and this is due to the impact of the COVID 19pandemic which was accelerating changes in event audience behaviour. This research will benefit the event organisers and help them prepare strategic plana to cater to the audience needs.
\end{abstract}

KEYWORDS: Event Industry, Readiness, Event Digitization, Covid 19

\section{PURPOSE AND BACKGROUND}

All the major industries of the world are currently dealing with the devastating effects of COVID-19 or known as coronavirus. Year 2020 has seen shifts in the way businesses and organisations operate in the wake of the deadly virus affecting everything from manufacturing to marketing. The events industry just like the other business industry has also been badly hit by the COVID-19 pandemic.

Most of the events were cancelled or postponed all over the world, including in Sabah. The events industry has been strongly affected by the disruptive effects of the COVID-19 pandemic. Event organisers are required to follow the guidelines set by public health officials and the direction of the local government to help stop the spread of the virus.

Therefore, The World Health Organisation (WHO) also recently published a document that offers both general and COVID-19 specific considerations for organisers hosting large events. In this unusual scenario, event organisers are required to reconsider their options and to balance their priorities which is to uphold the health and safety of staff, sponsors, and attendees.

Additionally, the event organiser needs to come up with different strategies to sustain their event business. Over the past few weeks, a significant number of meetings and conferences have been redesigned as virtual events. If adaptable, this meeting format is probably the best alternative in these challenging times. By their very nature, virtual events allow attendance irrespective of travel restrictions and facilitates the delivery of vanguard information. 
Moreover, this format is perfectly compatible with event marketing and sponsorship strategies while allowing planners to be ready for any eventuality. If they are strategically planned to use the right technologies, virtual events can reach a wider audience than traditional live events.

However, the event industry needs to know the perceptions and the readiness of the public towards the shifting from the physical events to the digital events, especially in Sabah. For some of the event audience this is a new norm for them. In additional, not all communities have their accessibility to the internet connection. Therefore, this study seeks to investigate the perceptions and readiness of the public for digital events.

\section{METHODOLOGY}

The study has been conducted in Kota Kinabalu, Sabah with the aim of examining the audience readiness for digital events. The study used quantitative approach and use the structured questionnaire as the research instrument. The target population of this study is the event audience that have attend any online event. The questionnaire was distributed using google form. A total of 169 respondents has participated in the data collection. The study used a five-point Likert scale in the survey instrument, which ranging from strongly disagree (1) to strongly agree (5). Event audience readiness was measured from 4 dimension according to the TRI namely optimism, innovativeness, discomfort, and insecurity.

\section{FINDINGS}

The findings of the study further prove the TRI model as developed by Parasuraman (2000) can indeed prove the event audience readiness towards event digitization. This study shows that the 4 dimensions of event audience readiness which represent by optimism, innovativeness, discomfort, and insecurity are positively impact on the behavioral intention in adopting the new ways of attending an event.

Overall, the event audience are ready to use and are adapting to the new event style even though there is some discomfort and insecurity in attending the virtual event. The COVID 19 pandemic is accelerating changes in event audience behavior. Event audience willingness to adopt digital is reflected in attitudes towards online events.

\section{CONCLUSION}

It is important for the event industry to know the readiness and a good online platform in providing a good service to their audience. Based on the result, we can see how far our communities is ready to adapt the new norm. Studies on the adoption of new technology are not new, however studies relating the readiness of the event audience toward the digitalization are relatively new considering the fact that now most of the event is going virtually.

\section{CONTRIBUTION/PRACTICAL IMPLICATIONS}

The result of this research also will assist the State Government to facilitate the communities for what their lacking in term of technology infrastructure. Besides that, further research is needed as this study only focus on the readiness and intention and not on the competencies of the audience in using the new technology. This research also will benefit the event organizer and they can prepare strategic plan to cater their audience needs. 


\section{ACKNOWLEDGEMENTS}

The authors would like to acknowledge the Research and Innovation Management Centre, Universiti Malaysia Sabah, for funding this research project (Grant No: SDK0201-2020).

\section{REFERENCES}

Loebbecke, C., \& Picot, A. (2015). Reflections on societal and business model transformation arising from digitization and big data analytics: A research agenda. Journal of Strategic Information Systems, 24, 149-157.

Parasuraman, A. (2000). Technology Readiness Index (TRI) a multiple-item scale to measure readiness to embrace new technologies. Journal of Service Research, 2(4), 307-320.

World Health Organization. (2020). Report of the WHO-China Joint Mission on Coronavirus Disease 2019 (COVID-19). 